\title{
Heart Valve Sewing Ring Device
}

National Cancer Institute

\section{Source}

National Cancer Institute. Heart Valve Sewing Ring Device. NCI Thesaurus. Code C50150.

A ring of supportive material around a heart valve designed to provide a stable surface

for attachment to surrounding tissues. 